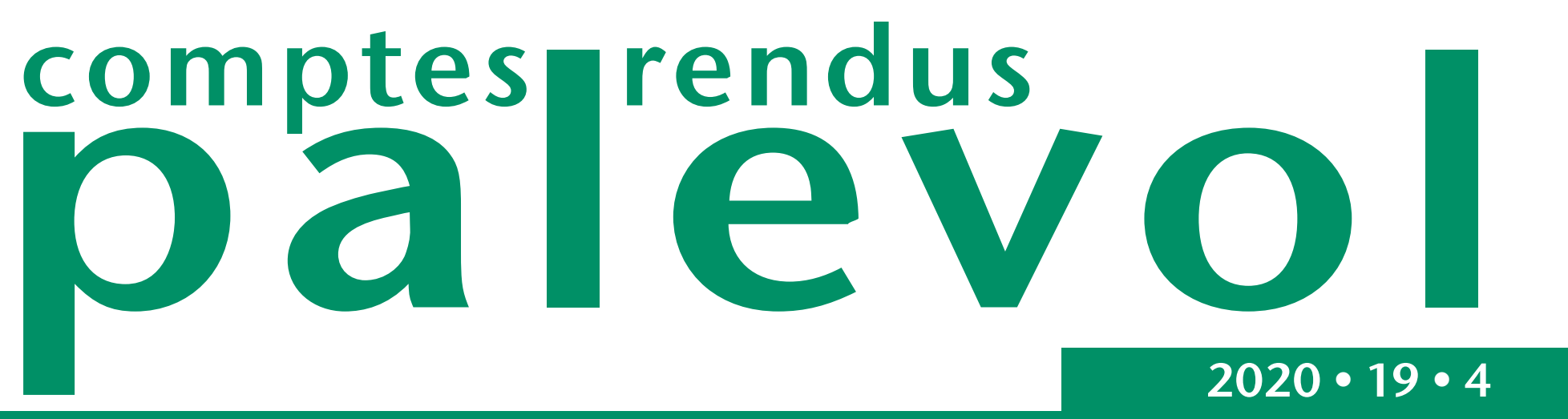

\title{
Analysis of portable rock art from Foz do Medal (Northwest lberia): Magdalenian images of horses and aurochs
}

Sofia SOARES DE FIGUEIREDO, Natália BOTICA, Primitiva BUENO RAMIREZ, Anna TSOUPRA \& José MIRÃO 
DiRECTEURS DE LA PUBLICATION / PUBLICATION DIRECTORS:

Bruno David, Président du Muséum national d'Histoire naturelle

Étienne Ghys, Secrétaire perpétuel de l'Académie des sciences

RÉDACTEURS EN CHEF / EDITORS-IN-CHIEF: Michel Laurin (CNRS), Philippe Taquet (Académie des sciences)

AssistANTE DE RÉDACTION / AssistANT EDITOR: Adenise Lopes (Académie des sciences; cr-palevol@academie-sciences.fr)

MISE EN PAGE / PAGE LAYOUt: Martin Wable, Emmanuel Côtez (Muséum national d'Histoire naturelle)

RÉDACTEURS ASSOCIÉS / ASSOCIATE EDITORS ( ${ }^{*}$, took charge of the editorial process of the article/a pris en charge le suivi éditorial de l'article):

Micropaléontologie/Micropalaeontology

Maria Rose Petrizzo (Università di Milano, Milano)

Paléobotanique/Palaeobotany

Cyrille Prestianni (Royal Belgian Institute of Natural Sciences, Brussels)

Métazoaires/Metazoa

Annalisa Ferretti (Università di Modena e Reggio Emilia, Modena)

Paléoichthyologie/Palaeoichthyology

Philippe Janvier (Muséum national d'Histoire naturelle, Académie des sciences, Paris)

Amniotes du Mésozoïque/Mesozoic amniotes

Hans-Dieter Sues (Smithsonian National Museum of Natural History, Washington)

Tortues/Turtles

Juliana Sterli (CONICET, Museo Paleontológico Egidio Feruglio, Trelew)

Lépidosauromorphes/Lepidosauromorphs

Hussam Zaher (Universidade de São Paulo)

Oiseaux/Birds

Éric Buffetaut (CNRS, École Normale Supérieure, Paris)

Paléomammalogie (petits mammifères)/Palaeomammalogy (small mammals)

Robert Asher (Cambridge University, Cambridge)

Paléomammalogie (mammifères de moyenne et grande taille)/Palaeomammalogy (large and mid-sized mammals)

Lorenzo Rook (Università degli Studi di Firenze, Firenze)

Paléoanthropologie/Palaeoanthropology

Roberto Macchiarelli (Université de Poitiers, Poitiers)

Archéologie préhistorique/Prehistoric archaeology

Marcel Otte* (Université de Liège, Liège)

COUVERTURE / COVER:

Composition à partir d'illustrations de l'article / Made from the Figures of the article.

Comptes Rendus Palevol est indexé dans / Comptes Rendus Palevol is indexed by:

- Cambridge Scientific Abstracts

- Current Contents ${ }^{\circledR}$ Physical

- Chemical, and Earth Sciences ${ }^{\circledR}$

- ISI Alerting Services ${ }^{\circledR}$

- Geoabstracts, Geobase, Georef, Inspec, Pascal

- Science Citation Index ${ }^{\circledR}$, Science Citation Index Expanded ${ }^{\circledR}$

- Scopus ${ }^{\circledR}$

Les articles ainsi que les nouveautés nomenclaturales publiés dans Comptes Rendus Palevol sont référencés par: Articles and nomenclatural novelties published in Comptes Rendus Palevol are registered on:

- ZooBank ${ }^{\circledR}$ (http://zoobank.org)

Comptes Rendus Palevol est une revue en flux continu publiée par les Publications scientifiques du Muséum, Paris et l'Académie des sciences, Paris Comptes Rendus Palevol is a fast track journal published by the Museum Science Press, Paris and the Académie des sciences, Paris

Les Publications scientifiques du Muséum publient aussi / The Museum Science Press also publish:

Adansonia, Geodiversitas, Zoosystema, Anthropozoologica, European Journal of Taxonomy, Naturae, Cryptogamie sous-sections Algologie, Bryologie, Mycologie.

L'Académie des sciences publie aussi / The Académie des sciences also publishes:

Comptes Rendus Mathématique, Comptes Rendus Physique, Comptes Rendus Mécanique, Comptes Rendus Chimie, Comptes Rendus Géoscience, Comptes Rendus Biologies.

Diffusion - Publications scientifiques Muséum national d'Histoire naturelle

CP $41-57$ rue Cuvier F-75231 Paris cedex 05 (France)

Tél.: 33 (0)140794805 / Fax: 33 (0)1 40793840

diff.pub@mnhn.fr / http://sciencepress.mnhn.fr

Académie des sciences, Institut de France, 23 quai de Conti, 75006 Paris.

(C) Publications scientifiques du Muséum national d'Histoire naturelle / (c Académie des sciences, Paris, 2020

ISSN (imprimé / print): 1631-0683/ ISSN (électronique / electronic): 1777-571X 


\section{Analysis of portable rock art from Foz do Medal (Northwest lberia): Magdalenian images of horses and aurochs}

Sofia SOARES DE FIGUEIREDO

Lab2PT - Laboratório de Paisagens, Património e Território, Universidade do Minho (Portugal) and Área de Prehistória, Universidade de Alcalá (Spain) and Laboratório Hércules, Universidade de Évora (Portugal) sofia.figueiredo@geografia.uminho.pt (corresponding author)

Natália BOTICA Lab2PT - Laboratório de Paisagens, Património e Território, Universidade do Minho (Portugal)

Primitiva BUENO RAMIREZ

Área de Prehistória, Universidade de Alcalá (Spain)

Anna TSOUPRA

Laboratório Hércules, Universidade de Évora (Portugal)

José MIRÃO

Universidade de Évora (Portugal)

Submitted on 30 September 2019 | accepted on 25 November 2019 | published on 28 September 2020

KEY WORDS

Portable art,

Magdalenian,

Sabor valley,

Northwest Iberia, microscopic analysis.
urn:Isid:zoobank.org:pub:85773089-A93A-41A2-803F-645A58148087

Soares de Figueiredo S., Botica N., Bueno Ramirez P., Tsoupra A. \& Mirão J. 2020. - Analysis of portable rock art from Foz do Medal (Northwest Iberia): Magdalenian images of horses and aurochs. Comptes Rendus Palevol 19 (4): $63-77$. https://doi.org/10.5852/cr-palevol2020v19a4

\section{ABSTRACT}

Studies focusing on Palaeolithic portable rock art have a long tradition in Europe. Nevertheless, they tend to only focus over formal and stylistic criteria of the motifs, important as they provide chronologies for cave art. This article proposes a multiple approach to a sample of 25 engraved plaques of the Foz do Medal archaeological site, where horses and aurochs were depicted, in order to construct a preliminary model able to guide the future analysis of the whole collection composed of more than 1500 fragments. On the one hand, relevant archaeological data was collected and systematized into a database that can be subjected to statistical analysis, for which we develop different variables and their respective attributes. On the other hand, laboratory techniques of analysis and examination of materials were applied, valuing the motifs details, their potential surface treatment by fire or pigments ornamentation, as well as the identification of raw materials and their origins. In this article, we present the obtained results, which allow us to propose some hypotheses regarding the social importance of this specific kind of artefact, as well as its possible manipulations. 


\begin{abstract}
RÉSUMÉ
Analyse d'art rupestre portable de Foz do Medal (Espagne nord-occidentale) : images magdaléniennes de chevaux et d'aurochs

Les études centrées sur l'art rupestre portable Magdalénien ont une longue tradition en Europe. Néanmoins, elles tendent à ne considérer que les critères de forme et de style des motifs, importants en ce qu'ils fournissent des chronologies pour l'art des grottes. Cet article propose une approche multiple à partir d'un échantillonnage de 25 plaques gravées du site archéologique de Foz do Medal où ont été représentés des chevaux et des aurochs dans le but de construire un modèle préliminaire, capable de guider l'analyse future de la collection complète, composée de plus de 1500 fragments. D’autre part, des données archéologiques pertinentes ont été récoltées et organisées en une base de données qui permet une analyse statistique performante pour laquelle nous développons différentes variables et leurs caractères respectifs. En outre, des techniques de laboratoire pour l'examen et l'analyse des matériels ont été appliquées, pour apprécier les détails des motifs, leur traitement superficiel par le feu ou leur ornementation par des pigments, ainsi que l'identification des matériaux bruts et leur origine. Les résultats obtenus sont présentés dans cet article; ils nous permettent d'émettre des hypothèses sur l'importance sociale de ce type spécifique d'artéfacts, de même que ses manipulations potentielles.

potentielles.
\end{abstract}

Art portable

Magdalénien

Vallée de Sabor,

Espagne nord-occidentale, analyse au microscope.

\section{INTRODUCTION}

The scientific study of Paleolithic art began with the recognition and analysis of portable art. Nevertheless, the complexity and beauty recognized in some cave art panels, and the acceptance of its antiquity, at the beginning of the twentieth century, led to the assumption that cave art was the most important human expression, with mobile art becoming just a complement to its explanation, significant by providing chronologies (Moro Abadia \& González Morales 2004).

Therefore, laboratory techniques of analysis and material examinations only started to gain importance in the early 1990's, following the theoretical and methodological framework of the "chaîne opératoire", as proposed by Leroi-Gourhan and mostly applied to lithic analysis. The application of this methodological tool relies on the recognition that technical gestures express cultural traditions and cognitive aspects of prehistoric societies, and can therefore tell us more about the individuals or the social groups that produced them.

Previous studies determined the direction of the recording gesture, whether or not the lines were engraved by the same tool, the order in which they were made, and to recognize accidents or errors in the tracing. Investigations have been conducted in both organic raw materials such as bone, ivory, tooth and antler (Farbstein 2011; Fritz 1999a, b; Rivero 2016) as well as in mineral raw materials such as sandstone slabs, concretion stalagmite, quartzite pebbles and slate plaquettes(Aubry \& Sampaio 2012; Bosinski et al. 2001; D’Errico 1992, 1994; Rivero 2016).

Regarding slate plaquettes, sites such as Gönnersdorf in Germany and Fariseu in the Côa valley in Portugal, both open air sites, take on special importance. However, the studies carried out are limited since in the first case only a binocular lens was used (Bosinski et al. 2001) and, in the second case, a magnifying glass (Aubry \& Sampaio 2012). Therefore, application of other technologies, such as Scanning Electron Microscope, to slate and greywacke raw materials are a total novelty that will help us to better understand the gestures behind the objects.

Furthermore, these analyses still concern only a small fraction of portable rock art, mostly focusing on the classical geographical area of Paleolithic art, cave contexts and on specific chronological periods.

For this reason, it is important to address portable rock art at a larger temporal and geographical scale, integrating new territories such as Northwest Iberia and the Atlantic façade, and chronologies such as the Gravettian and/or the Solutrean, developing multiple approaches that take into consideration both archeographic and archeometric data. If we want to be able to use technique as an indicator, we then have to be able to build a solid database.

\section{MATERIAL}

Foz do Medal is an alluvial terrace located in the Sabor River valley, in the region of Trás-os-Montes (Northeastern Portugal) and, as the Côa valley is situated to the south, it is one of the most important tributaries of the Douro basin (Fig. 1).

The archaeological intervention at Foz do Medal was performed within the framework of preventive archaeology, in the building context of the Hydroelectric Explotation of BaixoSabor. This large-scale constructive work was responsible for the submersion of a 3000 hectares area.

Currently submerged, the Foz do Medal River Terrace was located in an open area of the valley, which allowed the 
formation of a large platform of fluvial origin, $9 \mathrm{~m}$ above the river level and $165 \mathrm{~m}$ above sea level. It was situated on the left bank of the Sabor River, and crossed by the Medal stream. In this large area, both margins of the Medal stream preserved evidence of Upper Pleistocene occupations (Fig. 2).

The archaeological interventions, both on the left and right platforms, took place between 2011 and 2013. On the left bank platform, a Solutrean occupation was documented (Gaspar et al. 2015a). On the right bank platform, a complex sedimentary sequence was identified, registering human occupations between the Middle Palaeolithic and the Middle Bronze Age, with important occupation levels from the Gravettian and Magdalenian periods (Figueiredo et al. 2014; Gaspar et al. 2014, 2015b, 2016).

Regarding the Palaeolithic portable art collection, in both platforms of Foz do Medal more than 1500 fragments were identified, distributed into Gravettian, Solutrean and Magdalenian contexts.

At the present moment, we consider that only a preliminary study has been conducted towards the Foz do Medal portable art collection. In fact, the first studies, framed by preventive archaeology, were limited in terms of time and the applied methods. Therefore, and as stressed in previous articles, we were aware that the first presented data would undergo changes once framed by a scientific project (Figueiredo et al. 2015a, 2016).

Considering the large number of decorated stone pieces that Foz do Medal provided, as well as bureaucratic constraints, the first selection of artefacts for analysis has been

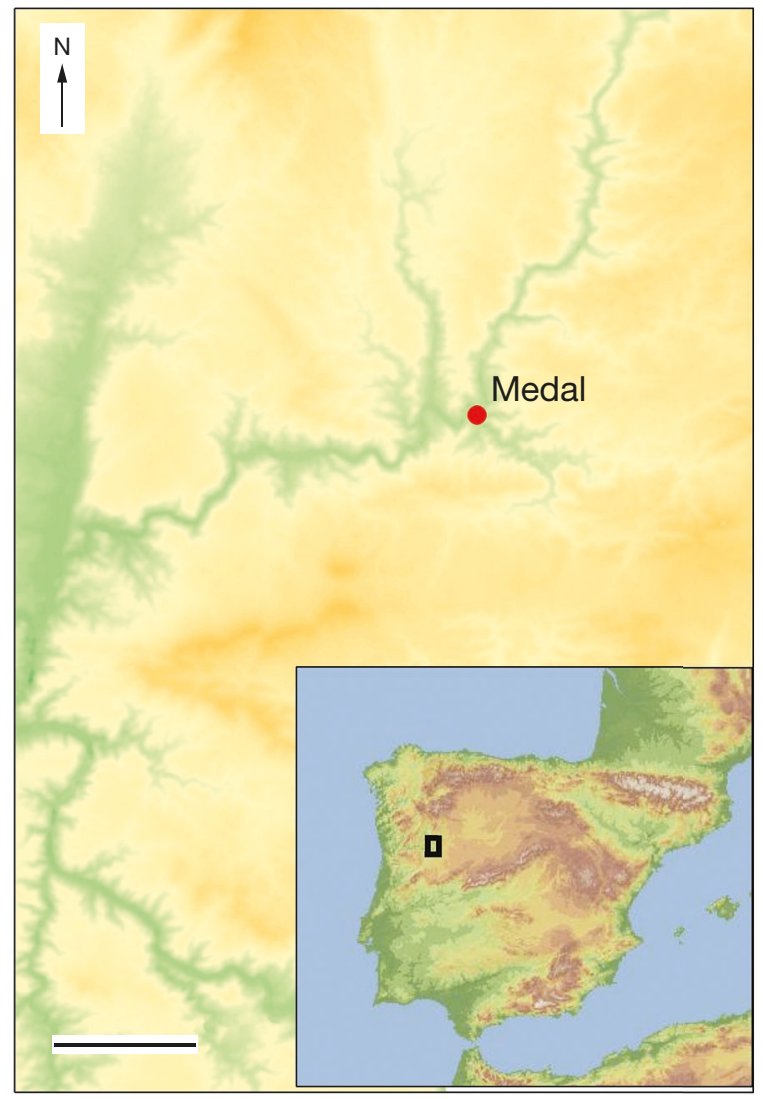

FIG. 1. - Location of the Foz do Medal site in the Sabor valley, Northwest Iberia. Scale bar: $3 \mathrm{~km}$

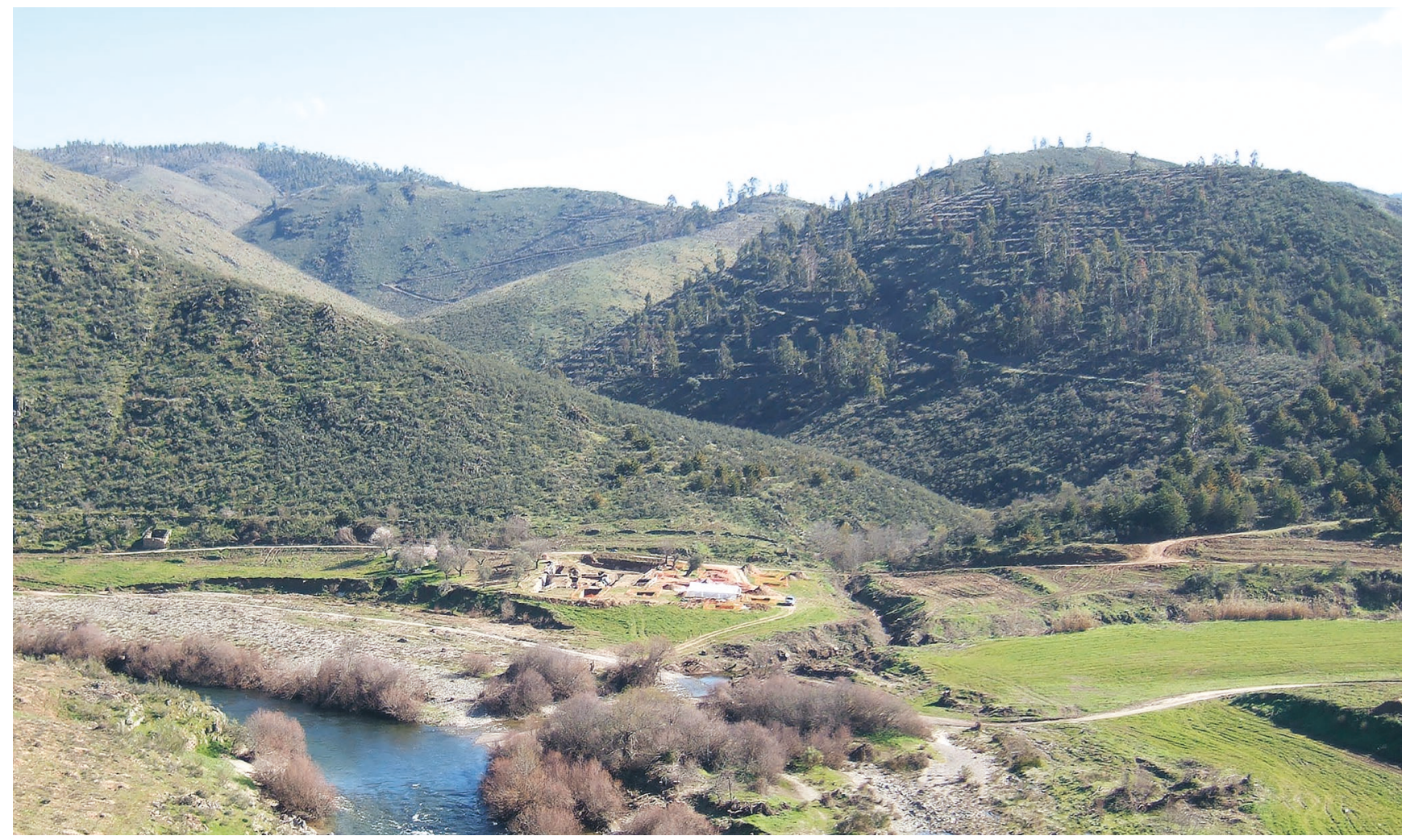

FIG. 2. - Right bank excavation overview. 


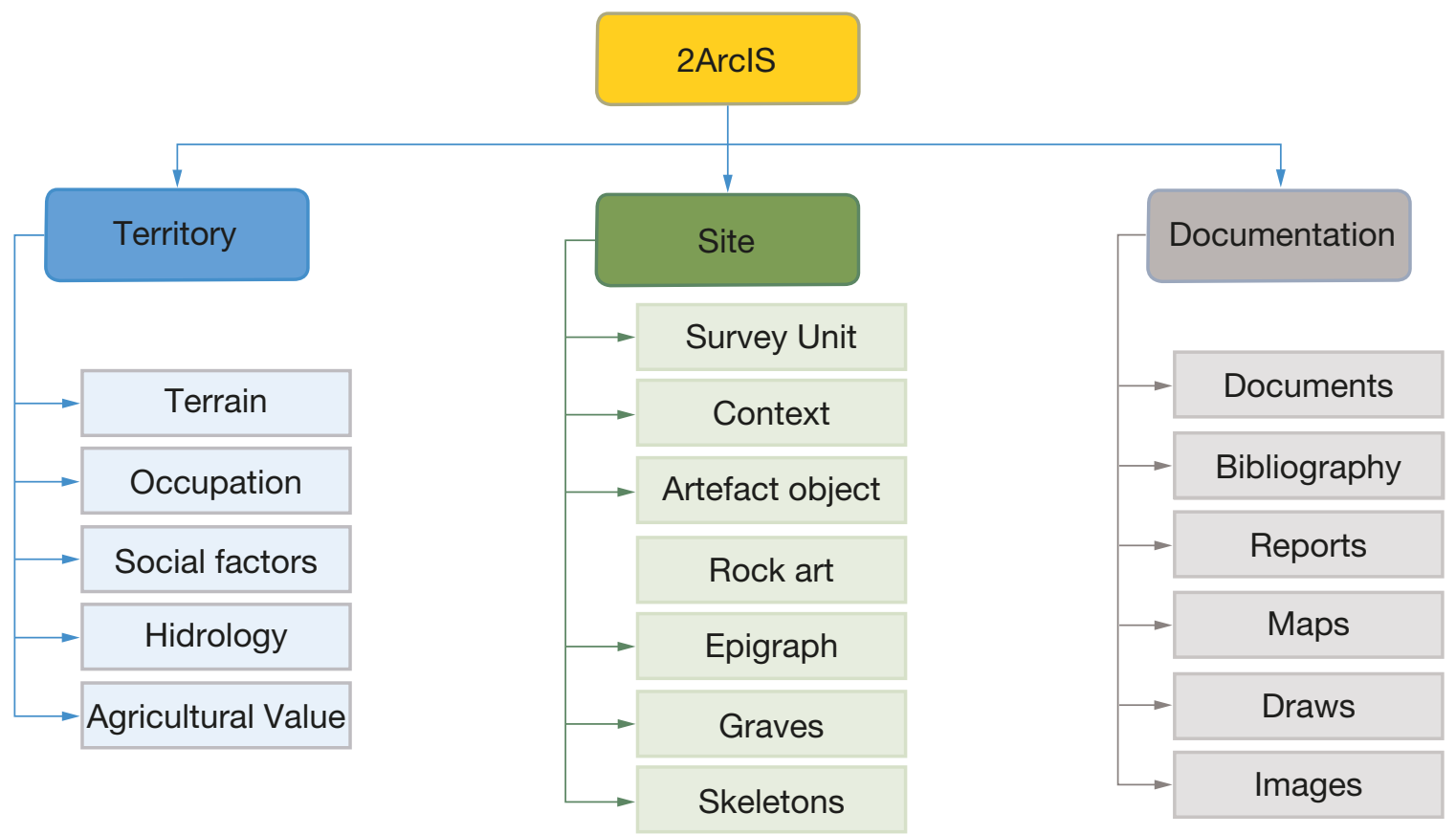

FIG. 3. - Relational model of 2 ArchIS to organize the archaeological data.

restricted. Therefore, and in order to achieve a consistent sample, we opted to examine a first set of monothematic supports, all from the same Magdalenian layer on the right bank platform, depicting the main figurative motifs represented in Magdalenian art, Equids and Bovids (Rivero \& Sauvet 2014) as dyad of fundamental symbols (Leroi-Gourhan 1995). Through this selection, we aim to determine some initial characteristics that will allow us to establish parallels with nearby geographical areas such as the Côa valley or Siega Verde. According to data produced in the first systematization work, 25 engraved stones corresponded to this description.

The Magdalenian layer [1055] corresponds to a coluvional facies with a thickness ranging from 5 to $20 \mathrm{~cm}$. In addition to the portable art, stone tools, fire structure elements, pigments, hammers and anvils were found. Samples were collected in sedimentary unit [1034], which covered the Magdalenian layer, and dated by Optically Stimulated Luminescence (OSL) to $12.350 \pm 930$, giving us the information that the occupation is prior to this date (Gaspar et al. 2016).

It is important to stress that the Magdalenian deposit, from where the 25 studied objects came out, results from the erosion of the original occupation and shows some postdeposition alteration. According to the estimate made, the occupation had a total area of $520 \mathrm{~m}^{2}$. A collection of 166 929 lithic pieces were collected,159 482 resulting from stone knapping. Although no hearths were identified, the presence of a large number of thermal-altered blocks and pebbles indicate that these structures would have existed at the site (Gaspar et al. 2015b). The presence of large slabs, some with engravings, also implies that the space was structured in some way.

\section{METHODS}

DATA MANAGING TOOL

A first task has been to verify and change, whenever necessary, the first collected data. For instance, the way in which the plaques and plaquettes are designated has been changed, in order to better perceive the collection. Although the respective numbering of each fragment was maintained, a distinct nomenclature was assigned to each plaque or plaquette, which may or may not consist of several fragments.

All rock art characterization attributes and associated metadata has been systematized according to the FAIR (Findable, Accessible, Interoperable and Reusable) principles of documentation creation for archaeological repositories. To perform this task, a database has been created for managing and protecting the digital data, and also for being able to realize statistical analysis on these data.

The characterization and descriptors used for the decorated pieces and their motifs were made according to the methods applied in Siega Verde and Côa Valley (Alcolea González \& Balbín Behrmann 2006; Aubry \& Sampaio 2012; Santos 2017; Santos et al. 2018). All collected data are being stored in the 2ArchIS Information System of the University of Minho.

The Information System of the Archeology Unit of the University of Minho 2ArchIS, was first developed with the aim of hosting and managing information associated with the archaeological project of Bracara Augusta (Giestal \& Martins 2000). It became an essential data management tool, facilitating the study and scientific divulgation of the project. Since then, its initial configuration has evolved, in order to adopt standard information design of archaeological databases and to integrate a wide-range of archaeological data, functions and analyses. 


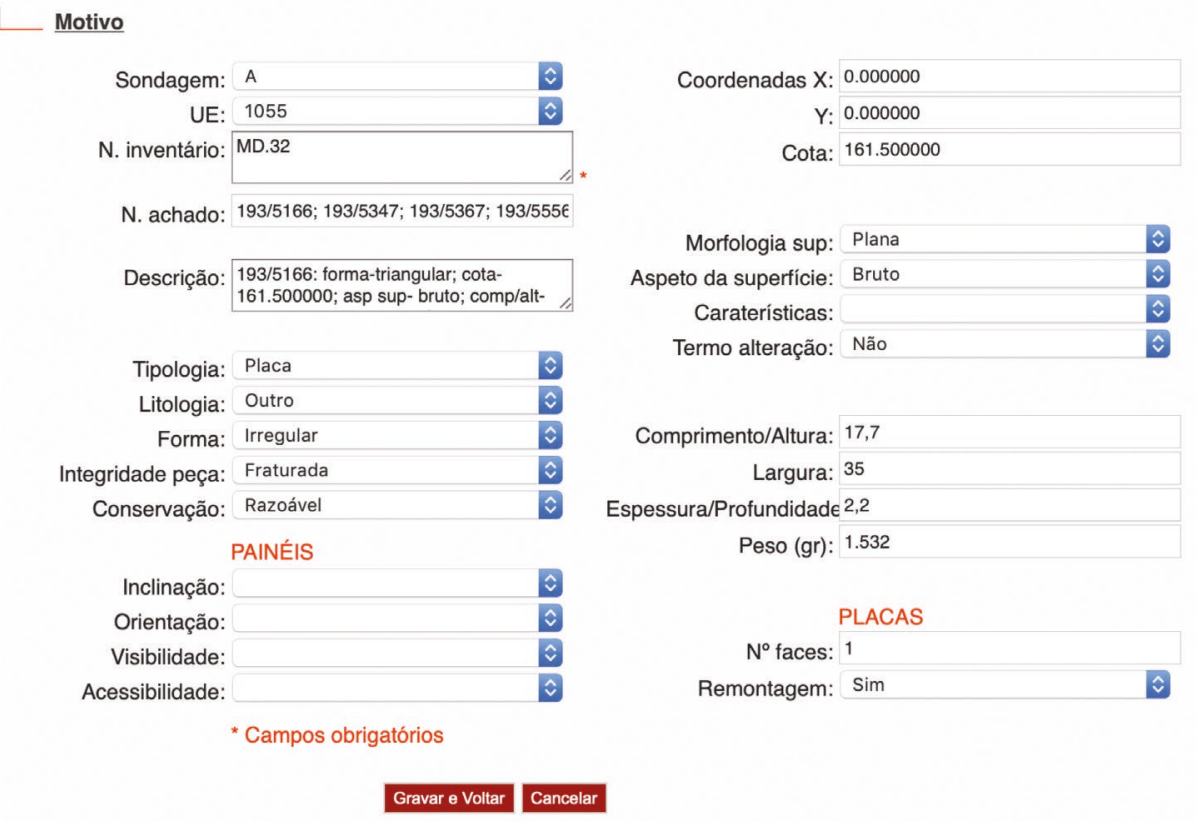

FIG. 4. - Foz do Medal portable rock art database. Registration form, ensuring the connection between the survey and the context from which it originated.

2ArchIS is an object-oriented relational model that organizes the archaeological data, in particular the digital data, into a structured and interrelated model, having a great concern towards the normalization and standardization of the data (Botica 2017). Its main output is materialized by a website with access to all the data that characterizes a particular archaeological site. Archaeological data from sites are associated with surveys, contexts and artifacts, allowing these entities to be linked to information regarding territory, cartography, images and bibliography (Fig. 3).

Archaeological data can be recorded in the field and completed in the office, using a BackOffice application developed in HTML and PHP, with connection to a database implemented in MySQL. The 2ArchIS platform is independent of the operating system used and is available in a WEB browser (Fig. 4).

Metadata is further associated in the 2ArchIS application to one or more rock images and image-based 3D models produced from photographs using the Structure from Motion (SfM) technique. The use of the integrated management system of metadata, images and 3D models enables the storage and management of information, and supports the investigation of rock art. Its dissemination in open data will certainly increase its reuse allowing new studies or new interpretations.
In order to perform more complex statistical calculations and quickly visualize the results, SPSS - Statistical Package for Social Sciences - was also used. The systematized data was transferred to SPSS and properly adjusted (e.g. establishment of the measurement scale for each variable). In order to understand the nature (intensity and degree of association) of the relationships between the variables considered, we assess their potential correlations (Figueiredo 2017).

\section{RECORDING METHODS}

In the scope of preventive archaeology, the first records were made by direct tracing, following the procedures dictated in the Plan for Cultural Heritage Preservation (PSP 2009). For this scientific project, we chose a less subjective and less invasive recording method, using only digital technologies (Fritz \& Tosello 2007; Brady et al. 2017).

The different supports were photographed individually using low light schemes. The camera was arranged with a tripod, in an upper plane perpendicular to the stone surface, adjusting the flashes and LEDs in the lateral zones. We used a Canon 5D Mark II camera with 21 megapixels resolution; three different lenses - Canon EF $50 \mathrm{~mm}$ f/2.5 Compact Macro, Canon EF 100mm f/2.8 Macro USM 


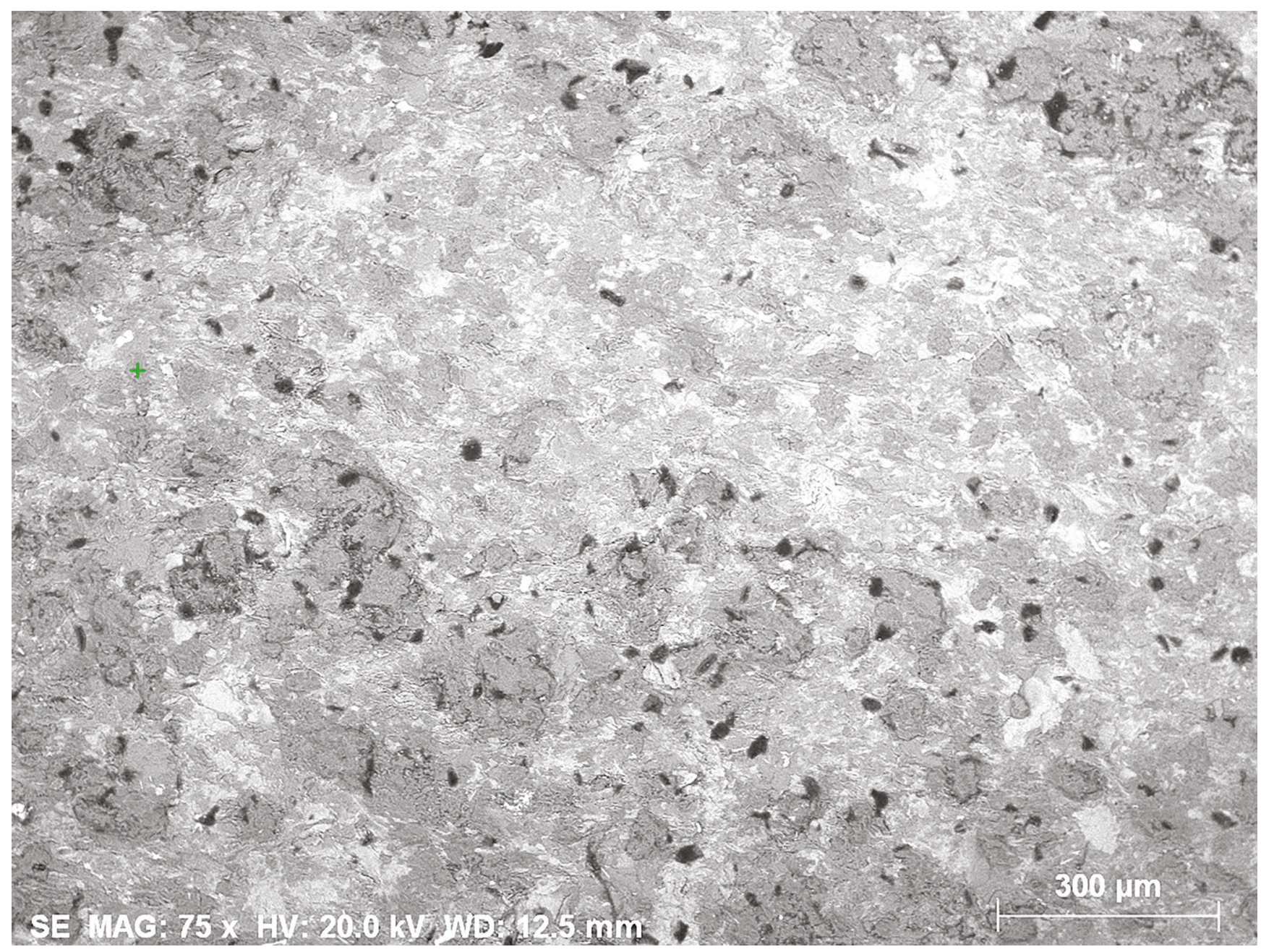

FIG. 5. - Example of SEM image taken on the plaquette MD.49 (Point 1), for the chemical analysis data acquisition where the green cross shows the examined mineral: albite.

and Canon EF 16-35mm f/2.8L II USM- depending on our registration goals; and a Color Calibration Table QPcard203 book. We used Adobe Photoshop and Adobe Bridge to edit the photos.

In addition, we preformed new tracings using only photography. This method revealed itself to be much more accurate, becoming the engravings much easier to see avoiding direct contact with the support. This method also eliminates the irregularity of the surface. Another advantage is the fact that we can use the original engraving for comparison and verification if necessary, in order to make corrections. Having this in mind we also used a binocular lens, Nikon SMZ645, which allowed us enlargements up to $\times 10$, making it possible to observe details that otherwise were not visible. This technique is special useful in the understanding of overlapping traces.

Through this method and using suitable software such as Adobe Photoshop; Adobe Illustrator and Adobe Sketch, a file was produced containing different layers of information, reproducing the maximum possible features, making it easy to manipulate or change according to new data or the image we want to display.

\section{ANALYTICAL CHARACTERIZATION}

Regarding the perception of the motifs, its construction and overlapping, besides the binocular lens and for further detail, a Scanning Electron Microscope was employed for the pieces MD.32, MD.35, MD.48 and MD.49. These engraved stones were chosen due to their representations and the different techniques employed in their construction, as well as the raw material.

The equipment used for the analysis of the samples was a variable pressure Scanning Electron Microscope HITACHI S-3700N, operated with an accelerating voltage of $20 \mathrm{kV}$ and chamber pressure of $40 \mathrm{~Pa}$. A Bruker XFlash 5010 Silicon Drift Detector (SDD) with a resolution of $129 \mathrm{eV}$ at Mn Ka was used for the chemical analysis data acquisition. The EDS point microanalyses and elemental distribution maps were processed with Esprit 1.9 software. The SEM images were captured in backscattering (BSE) and secondary electron (SE), always in variable pressure mode, without any coating. (Fig. 5).

Chemical data were obtained in order to characterize the rock samples and to identify possible traces of pigments. The SEM images were obtained in order to investigate technological issues regarding the engravings. 


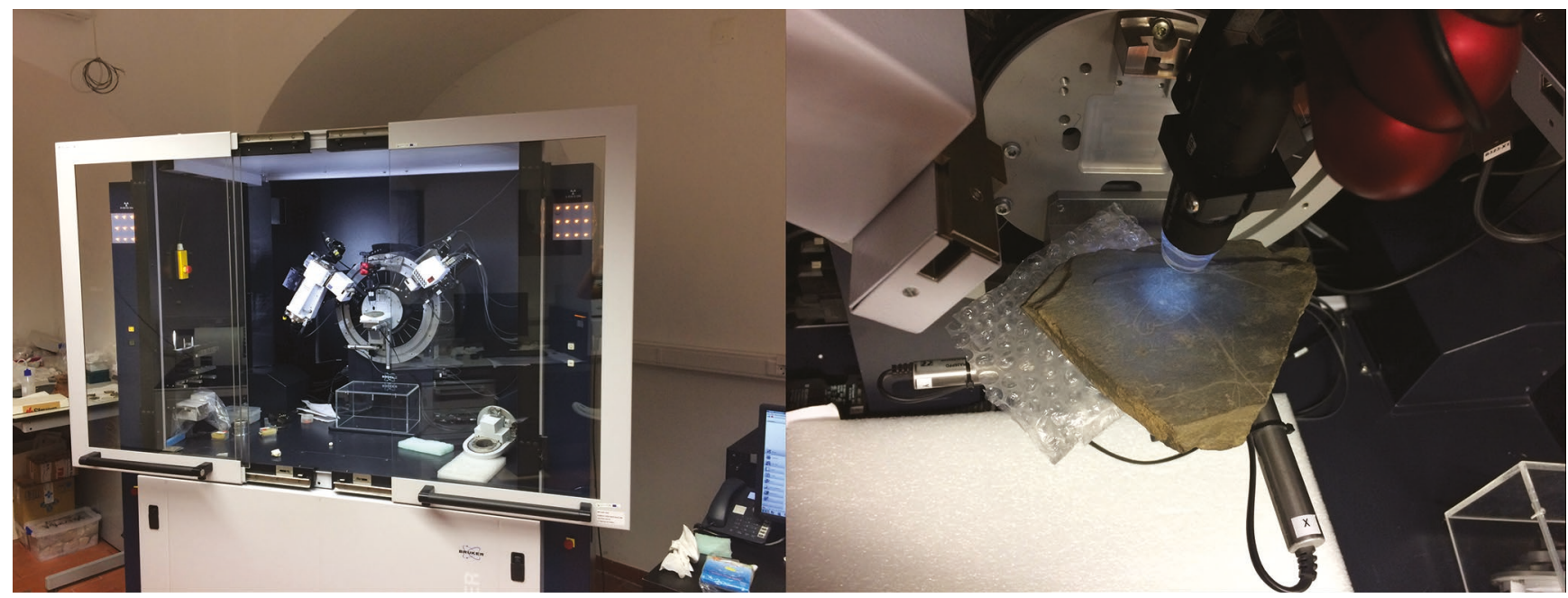

FIG. 6. - X-ray spectroscopy, coupled with scanning electron microscope and by X-ray diffraction.

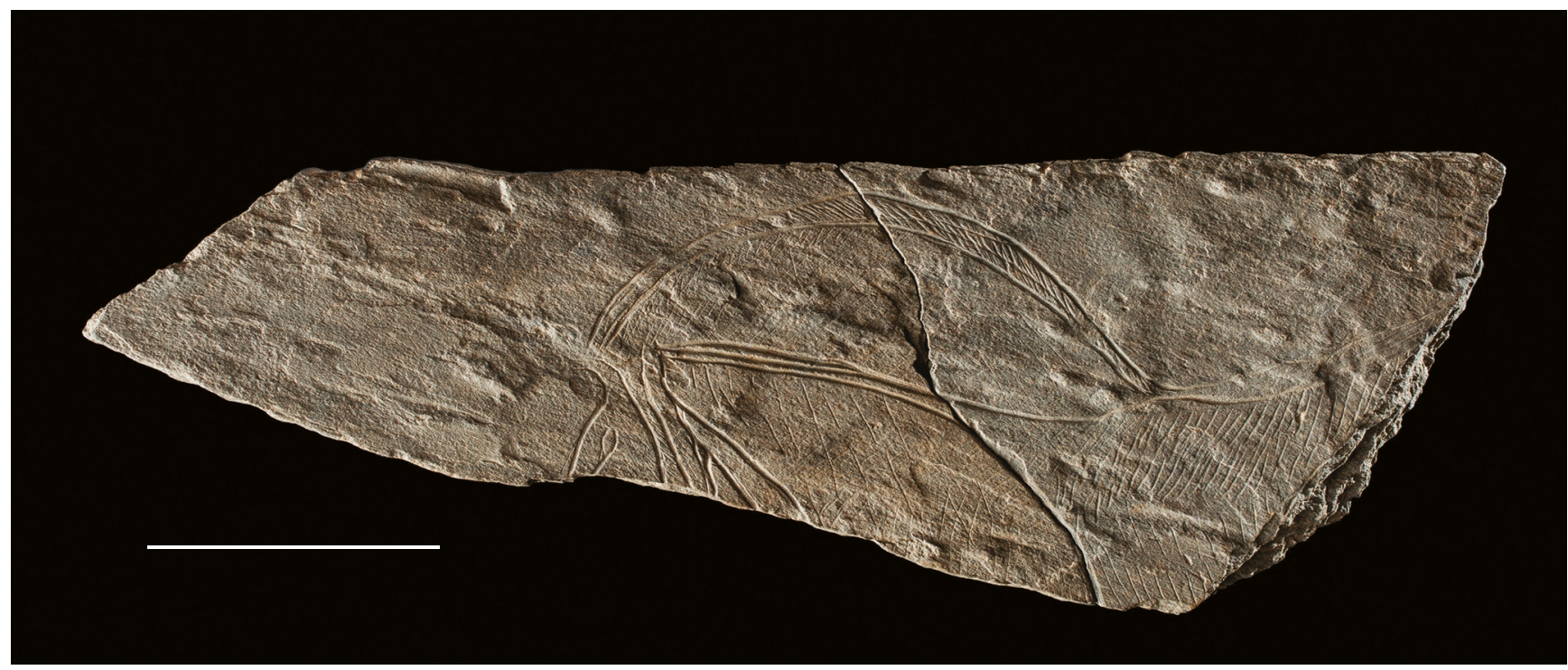

FIG. 7. - Slate plaque MD.45, depicting a detailed horse. The left fragment has a reddish colour and the right fragment has a grey colour. Scale bar: $5 \mathrm{~cm}$.

The potential treatment of the stone surfaces by fire or ornamentation by pigments was evaluated by X-ray spectroscopy, coupled with Scanning Electron Microscope (SEM-EDS) and by X-ray diffraction (Fig. 6). The first was used to detect the presence of pigments, while the second was essential in perceiving existing mineralogical changes made through fire exposure. Both techniques also allowed the determination of the mineralogical composition of the stone raw material. $\mathrm{X}$-ray diffraction was used in 19 decorated stones among the 25 samples. The samples were analyzed in a Bruker D8 Discover X-Ray Diffractometer with $\mathrm{Cu}$ Ka source at $40 \mathrm{kV}$ and $40 \mathrm{~mA}$. The patterns were collected at a 20 angular range of $3^{\circ}-75^{\circ}$, with $0,05^{\circ}$ step size and $1 \mathrm{~s}$ measuring time by point. The LYNXEYE linear detector provides an increased signal. Identification of minerals was performed using the DIFFRAC.SUITE EVA software and the ICDD PDF-2 database. The semi-quantitative determination of the mineral abundance in the bulk samples, obtained by the Reference Intensity Ratio (RIR) method.

\section{RESULTS}

The 25 engraved stone collection analyzed is very fragmented. Among the samples none is a complete object and 6 are the result of reassembly (Figueiredo et al. 2015b).

The average height is $9,1 \mathrm{~cm}$, with the smallest plaquette measuring $2,5 \mathrm{~cm}$ and the largest plaque $18,9 \mathrm{~cm}$. The average width is 13,4 , with the smallest plaquette measuring $3,1 \mathrm{~cm}$ and the largest plaque $27,1 \mathrm{~cm}$. The thickness ranges from values between 0,3 and $2,8 \mathrm{~cm}$, with an average of $1,2 \mathrm{~cm}$. The weight varies from 3 grams up to 1532 grams, with an average of 219 grams. According to the established parameters for mobile art (Tosselo 2003) and taking into account the presented measurements, 6 engraved stones were framed into the typology of plaques while 19 were framed 


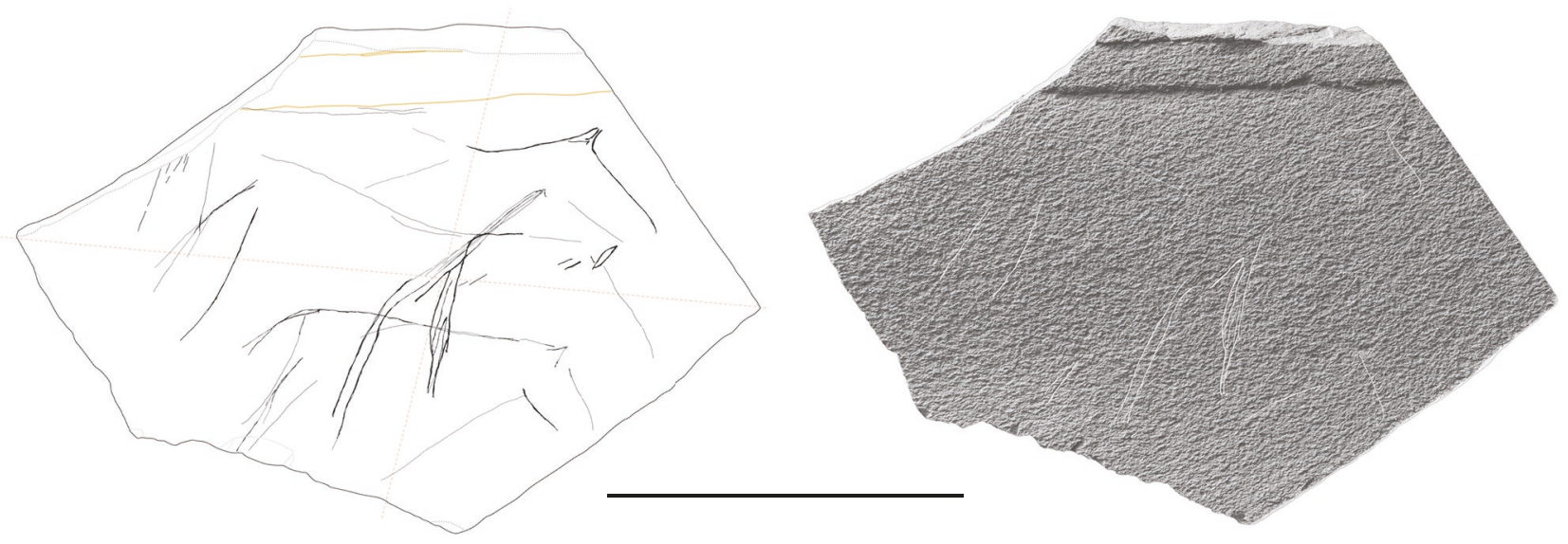

FIG. 8. - Greywacke plaque with very thin incised lines. Comparison between the first and second recording methods. Scale bar: $10 \mathrm{~cm}$.

into the typology of plaquettes (parallel faces, under $20 \mathrm{~cm}$ across). However, it is important to take into account that due to the fragmentation of the collection, some pieces classified as plaquettes could correspond to plaques in the past.

Two raw materials are present. Eleven pieces are greywacke and other eleven are slate. Three objects are greywacke and slate, presenting two different surfaces (MD.29; MD.32; MD.53).

The analysis and materials examination, both X-ray spectroscopy, coupled with scanning electron microscope and $\mathrm{X}$-ray diffraction, showed that in the analysed pieces, no treatment of the stone surfaces by fire or ornamentation by pigments was applied. Even in the two cases in which the pieces that make up the slabs have different colours (MD.45; MD.48). Therefore, this difference should rather be understood as the result of post depositional processes (Fig. 7).

Among the 25 objects, ten are engraved in both sides.

As already stated, the selection of the samples was made taking into account representations of horses and aurochs. Thus 18 engraved stones with representation of horses were selected and 7 with aurochs. However, due to the new recording methods, a slightly change in this cataloging occurred. Plaque MD.31 revealed very different motifs from the ones initially designed and, although we were able to distinguish extremely thin lines, we could only recognize what might be the top of a horse's head, although very dubious (Fig. 8). On plaquette MD.33, in addition to a horse, an ibex may also be represented (Fig. 11). On plaquette MD.34, the straight muzzle of the depicted animal suggests an aurochs and not a horse as catalogued. On plaquette MD.40, an ambiguous figure is depicted and not a horse as initially thought. On plaquette 47, the represented figure is an ibex and not an aurochs. And, on plaque MD.53, the depicted animal refers in some aspects to an aurochs (mouth, nostril and back line) but, in others to an ibex (head and tail). Thus, from the selected sample, we can consider the representation of 16 horses (including MD.31), six aurochs, one ibex and two ambiguous motifs very hard to classify.

Regarding the technique employed, most motifs were recorded by simple incisions. Only six plaques have combi- nations of simple incisions with repeated incision, multiple incisions or abrasion (MD.29; MD.32; MD.35; MD.45; MD.46; MD.52) and one presents pecking technique (MD.48).

Due to the fragmentation of the collection, most of the animals are not complete. The two exceptions are the horse on plaque MD.46 and the animal on plaque MD.53. The front of the animals as well as their heads are the most represented parts, although this may be due to the fact that these are the easiest parts to identify as being part of a figurative representation, whereas isolated legs or back lines are difficult to grasp. Fourteen figures are oriented do the left and eleven to the right.

There are no associations between the analyzed figures and other zoomorphic figures, although in 17 cases they are associated with abstract motifs. It is important to stress that abstract motifs may have corresponded to animal parts, but once the plaque was broken, they lost the possibility of this interpretation. In one plaque and four plaquettes the animals are associated to scattered pecking (MD.32; MD.33; MD.36; MD.41; MD.42).

At this time, through the statistical calculations performed, we were unable to obtain significant data interpretations. Or rather, significant correlations we obtained, were mainly relative to dimension variables that do not go beyond the meaning of any logical or metrical interpretation. Thus, there is a positive correlation between height and width, between width and the typology of the pieces, among others.

\section{DISCUSSION}

All the raw material is local and the community must have got it in the vicinity of the settlement. It is nevertheless interesting that none presents marks of burning, taking into consideration that there is a link between portable rock art and fire. In cave contexts, such as Labastide or Le Mas d'Azil, plaquettes were sometimes used in the construction of hearths (Bahn 1997). Pigments were not detected either, although metal oxides identified and interpreted 


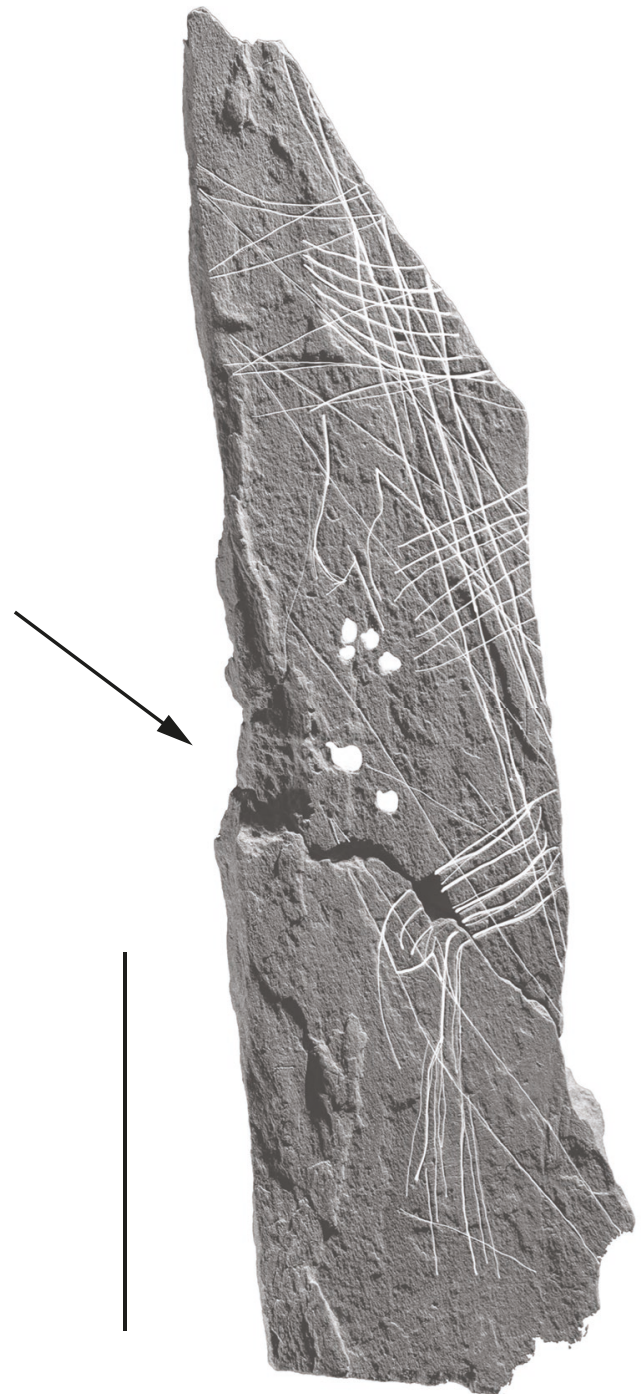

FIG. 9. - Slate plaquette with the representation of a horse's head, possible ibex and scattered pecking. The arrow shows where pecking was more intense causing a depression. Scale bar: $5 \mathrm{~cm}$.

as pigments were found in the sedimentary unit 1055. In some sites, such as La Marche, several plaquettes have pigments residues (Mélard 2008) and in the sample collected by D'Errico to study Epipaleolithic portable art, half of the faces had traces of colouring (D'Errico 1992).

Due to the context of the Magdalenian deposit, which is not in its original position leading to the fragmentation of the collection, it is very difficult to determine whether plaquette fractures are intentional or natural. In one case (MD.49) (Fig. 10) the piece was reconfigured. This may lead us to an explanation in line with Tosselo's interpretation for the archaeological site of Limeuil. According to this author, from the collection of a blank plaquette near the site, the cycle would have started with a first engraving, followed by the exposure to fire and fracturing, the collection of a broken fragment and the engraving of a new figure. This cycle would only be interrupted when the fragments became too small to be engraved (Tosello 2005). This sequence of gestures would have led to the presence of various overlapping as well as motifs of vary different sizes, as registered on sites like Limeuil, La Marche (Mélard 2008) or Gönnersdorf (Bosinski et al. 2001).

Taking into account our sample, and despite the presence of overlapping, this cycle is not the norm. If we consider the dimensions of some of the figures, for instance where only the head is represented, and we consider that the figure could have been complete or nearly complete, as in the MD.32 case (Fig. 11), the dimensions of most analyzed slabs would probably have been very large. Investigating the smaller figures, only one plaquette shows a considerable number of superimpositions (MD.33). This is an extremely interesting plaquette as it also has traces of intense and disperse pecking (Fig. 9).

Considering overlapping, it is interesting to notice that different phases seem to have been produced through different instruments, which may suggest the existence of a time gap between the engravings (Figs 11;12). Also interesting is the fact that 10 of the analyzed artifacts are engraved on both sides, including larger plaques, such as the case of MD.30 and MD.45 that implies some kind of manipulation.

In the SEM images, the differences between negatives resulting from simple incision, repeated incision and abrasion are rather clear (Figs 12-15). In the Figure 12B, C, we can observe that the major negative line has an extremely regular groove due to abrasion. Even more interesting is the fact that it is asymmetrical, with the right side being more inclined than the left, taking the front perspective. This suggest that the movement was done laterally, by someone right-handed, producing more pressure at that side. Another issue regarding the study of the technique and the produced negatives is related to the raw-material used. The lines of the figures engraved in greywacke always appear much more irregular than the ones engraved in slate (Figs 13 and 15). Therefore, we came to wonder if in Foz do Medal, raw material was a determinant factor when choosing the engraved figure and the degree of its detail. Although the more detailed figure of the analyzed sample is engraved in slate (Fig. 7), at this moment we were not able to correlate raw material and the quality or detail of the depicted figure. Nevertheless, this seems to have played a major role in the Cantabrian and Pyrenean Middle Magdalenian portable art with engravers with different degrees of experience working with different raw materials (Rivero 2016). None the less, it is important to remind us that this is a first sample of the Medal collection, and that we still lack observations made on engravings produced by experimental methods.

The presence of large plaques may indicate their use in the structuring of space. In Gönnersdorf, most of the engraved plaquettes were used as pavement within the living area. The study of themes and their spatial disposal led the authors to distinguish a different distribution among birds and mammoths, corresponding to different dwellings (Bosinski et al. 2001). Unfortunately, in the case of Foz do Medal, no structure nor spatial organization was identified due to post-depositional shifting. 


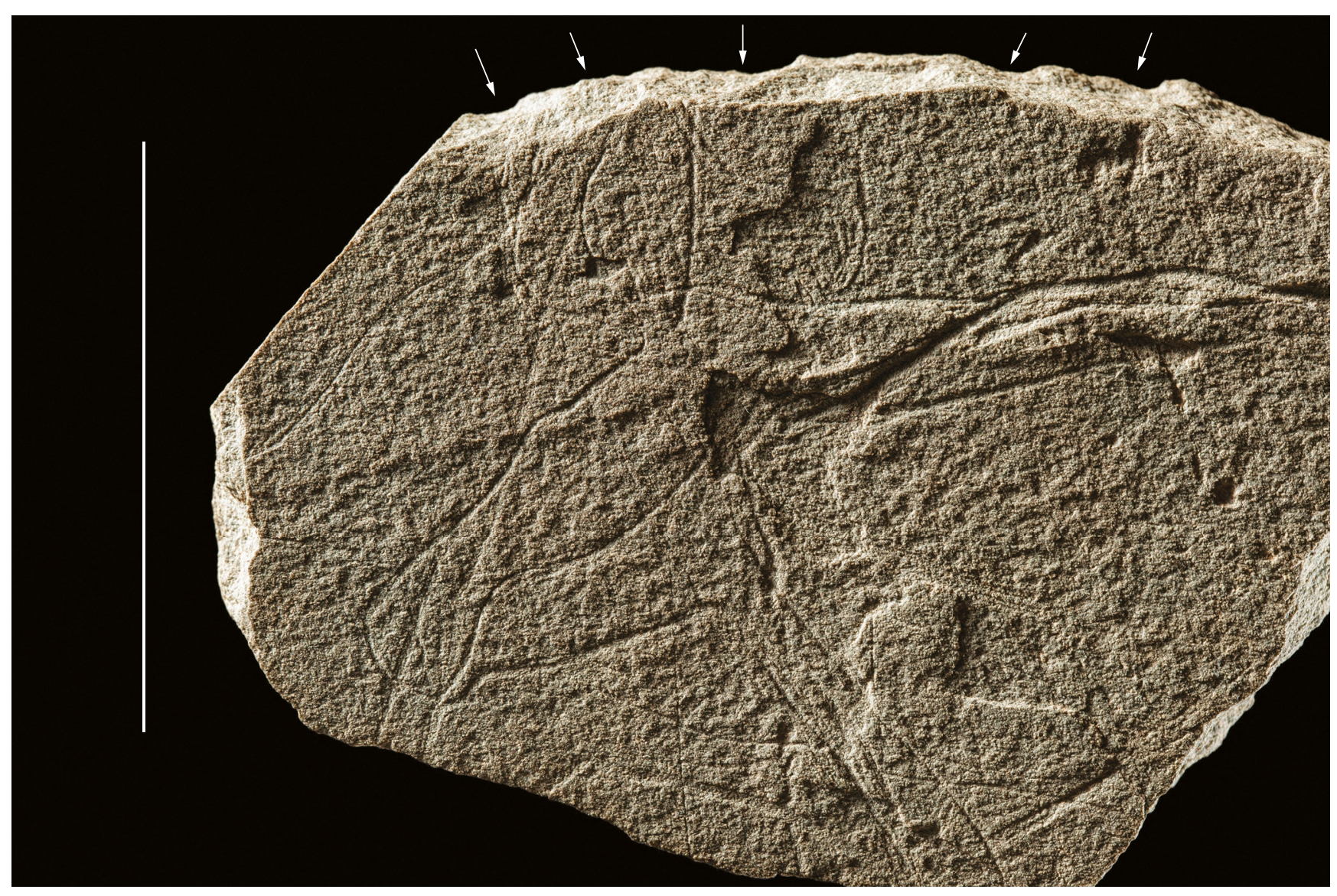

FIG. 10. - Greywacke plaquette MD.49 with an aurochs representation. The arrows show where the plaquette was reconfigured. Scale bar: $5 \mathrm{~cm}$.

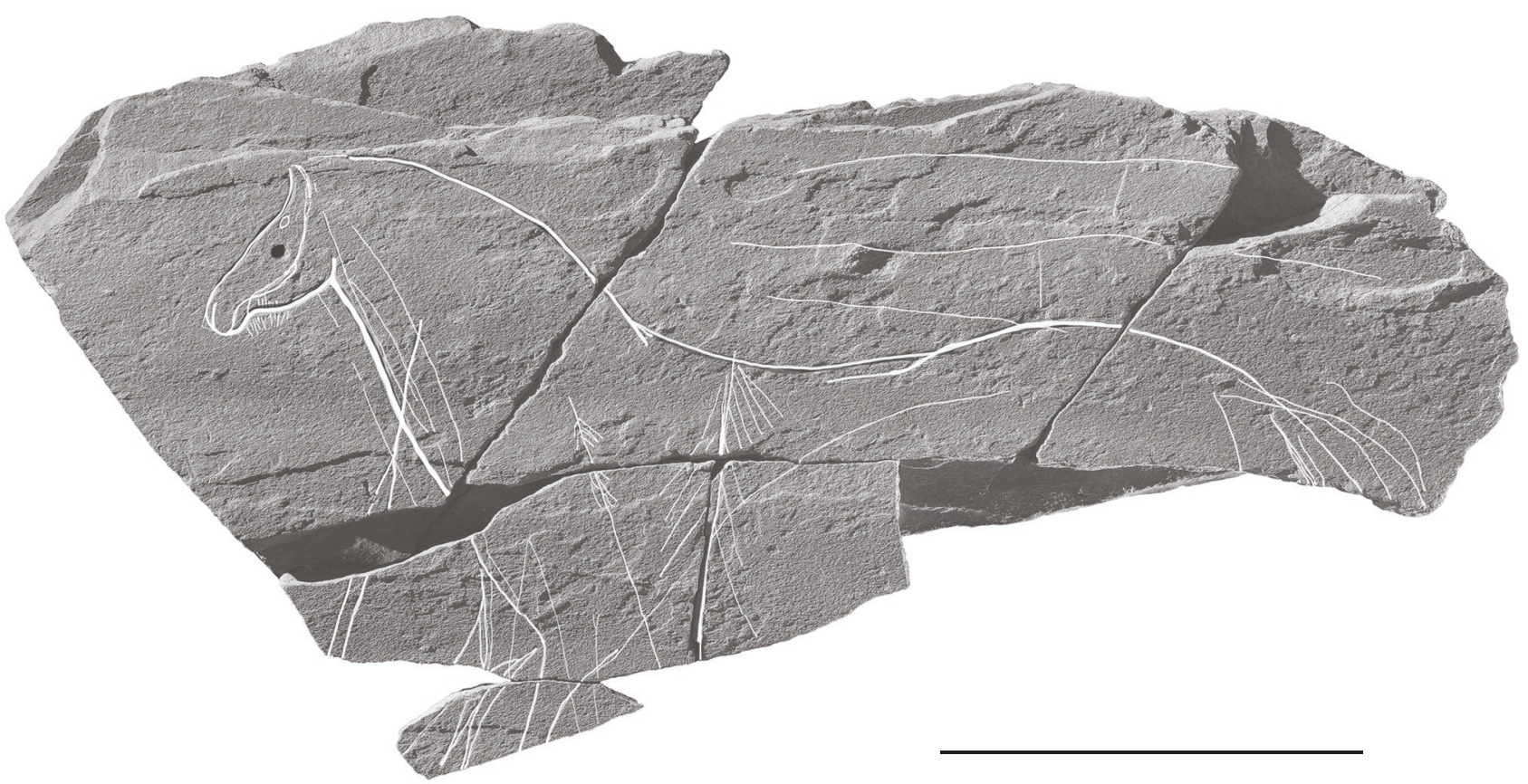

FiG. 11. - Greywacke and slate plaque MD.32. with a horse representation. Scale bar: $10 \mathrm{~cm}$. 


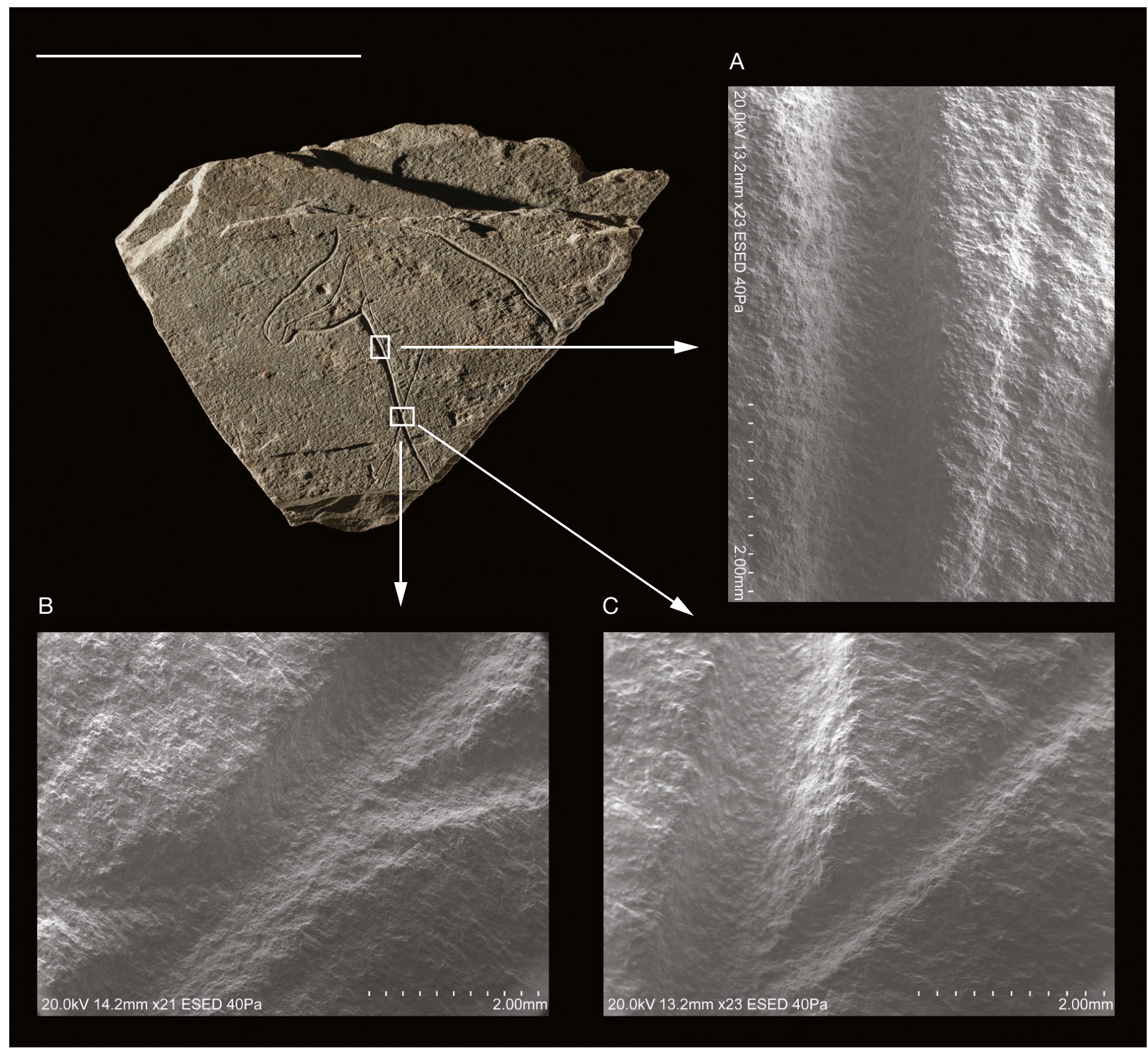

FIG. 12. - Sem images of plaque MD.32. In A, we see a regular groove while in $\mathbf{B}$ and $\mathbf{C}$ we can observe the asymmetric groove, with a larger slope on the right side. Scale bar: $10 \mathrm{~cm}$.

Considering the figured animals of our sample, both aurochs and horses show familiarity with style IV as defined by Leroi-Gourhan (1995). Taking into consideration the recent studies from the Côa valley, (Gameiro et al. 2020; Santos 2017; Santos et al. 2015), they integrate Phase 3. The animal representations attributed to this phase have well- proportioned bodies with naturalistic forms. The anatomical elements of the head are frequent, such as mouths, ears, perimetrically delimited nostrils and almond-shaped eyes. The chromatic variation of the coat and the intugmenta in the head and limbs is also common. Two pairs of legs are usually represented with hooves, often in uni-angular profile. The most common technique is the incision, which appears in simple and repeated forms, although pecking and abrasion are also identified (Santos 2017).
The most evident parallels to this phase are found in the Franco-Cantabrian region, in contexts attributed to the middle and upper Magdalenian. Examples can be found in Les Trois Frères, Niaux, Santimamiñe, Alkerdi and Ekain. In the Côa valley, rock 24 of Piscos and rock 41 of Canada do Inferno contains these kinds of figures. In Siega Verde, the figures ascribed into this phase are distributed mainly in the northern sector of the site, where horses are depicted with an inner body line modeling an $\mathrm{M}$ shape.

Nevertheless, it is worth noticing that in the Côa valley, Phase 3 was studied together with Phase 2, given the low number of motifs and the lack of investigations in the archaeological sites where they are present (Santos 2017). Considering the main four themes of Paleolithic art in west Iberia, the thematic distribution is different 


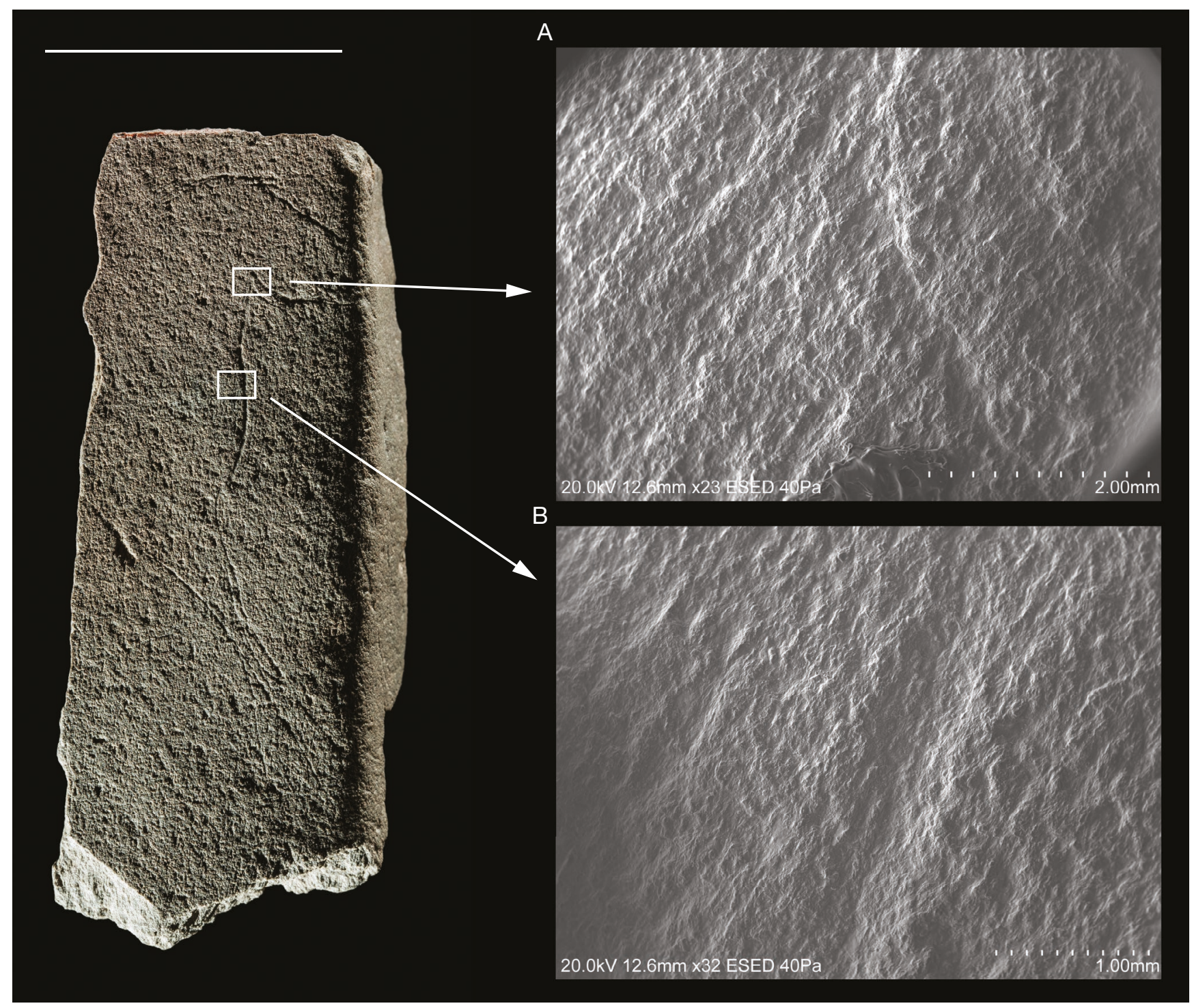

FIG. 13. - SEM images of Plaquette MD.35 representing a horse through single incision. Scale bar: $4 \mathrm{~cm}$.

in the Côa valley, the Foz do Medal and Siega Verde. In the first case the sequence, taking into account the order of its importance, is horse, auroch, red deer stag and ibex (Gameiro et al.2020). In Foz do Medal it is ibex, horse, auroch, with red deer being very rare (Figueiredo et al. 2015a). In Siega Verde, the order is similar to the one reported in the Côa valley, although with strong differences in the percentages (Alcolea González and Balbín Behrmann 2006). In Cantabria, it is with the Magdalenian style that the number of ibex representations increases, even becoming the dominant animals in caves such as El Bosque or Covarón (González Sainz 2010).

In Foz do Medal it is also important to note what seems to be the presence of small figures, with elongated or excessively rounded bodies, sometimes filled, and without any anatomical details. These figures may be similar to others in western Iberia (Bueno Ramírez et al. 2007, 2009), and their presence in Foz do Medal leads to discussion of its relationship with more naturalistic elements, in the sense pointed out by Lorblanchet (1989) about sites in Southern France: coexistence and overlap. Although a discussion about styles is not our goal, it is important to note the presence of Style V in the plaquette MD.33 (Fig. 11), probably depicting ibex arranged vertically, similar to a scene also present in the panel 48 of Siega Verde, superimposed to a horse representations (Bueno Ramírez et al. 2016). This may indicate a close relationship between portable and parietal art, entirely new in the geography of southern Europe.

Phase 3 denotes important relations between the North of Portugal and the Cantabrian region. This relationship accentuates the importance of a region that until the late twentieth century was not even part of the paleolithic rock art map. The recent discoveries in Portugal and Galiza have incorporated the entire West of the Iberian Peninsula into the complex world of Palaeolithic Art, with numerous archaeological sites 


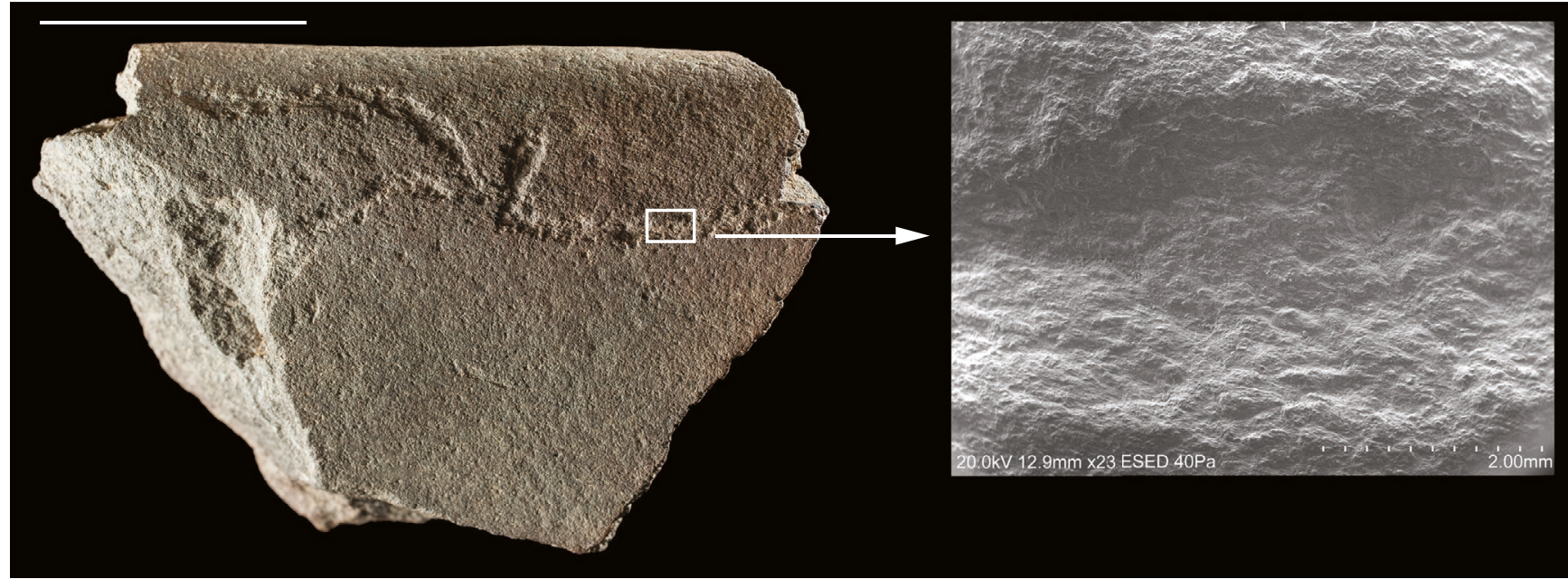

FIG. 14. - SEM image of Plaquette MD.48 representing an aurochs through pecking engraving. Scale bar: $4 \mathrm{~cm}$.

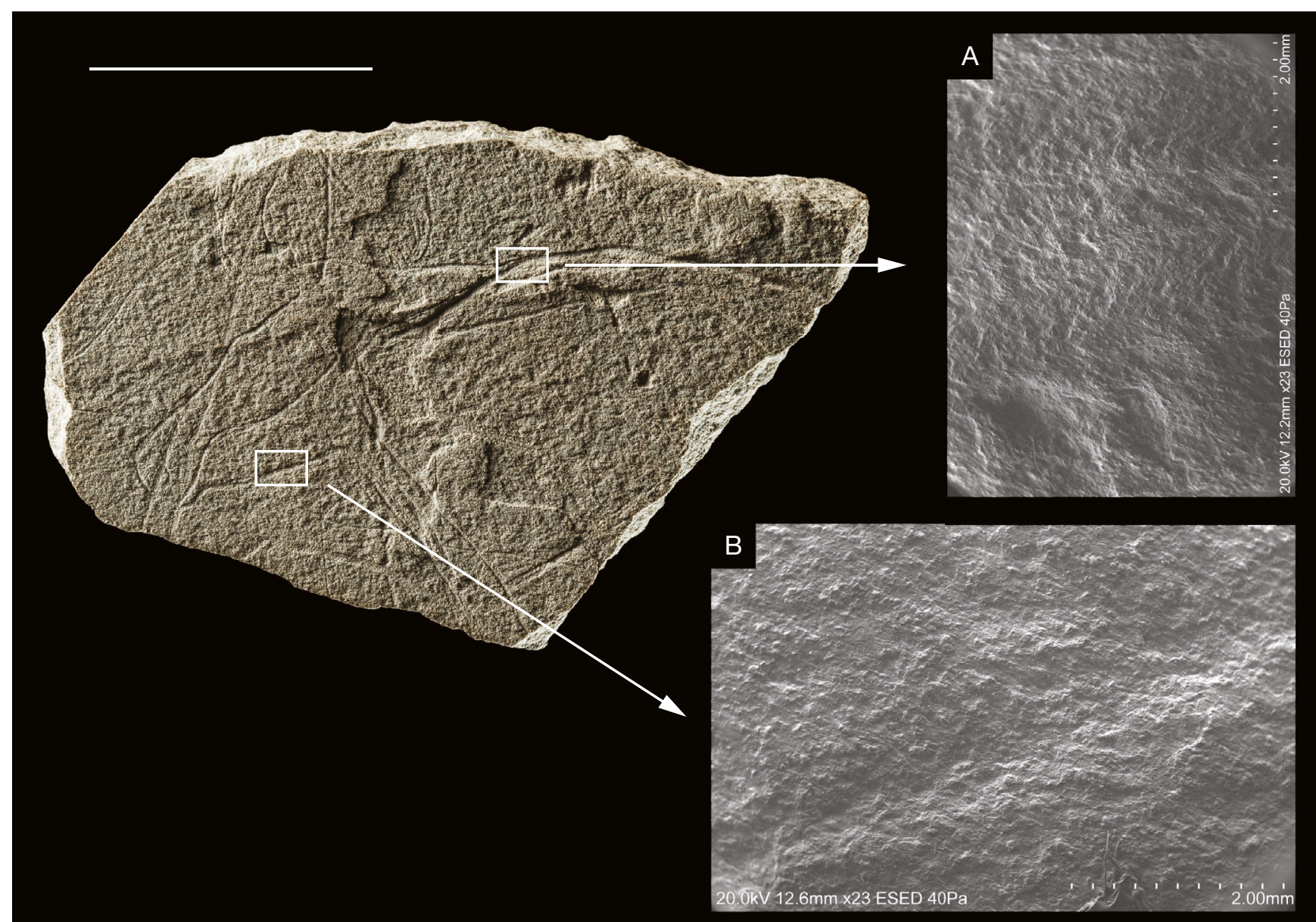

FIG. 15. - SEM images of Plaquette MD.49. Scale bar: $4 \mathrm{~cm}$.

displaying parietal art both in caves and open-air sites, as well as significant portable art collections, as is the case of Foz do Medal (Fábregas Valcarce et al. 2015; Lombera Hermida \& Fábregas Valcarce 2013; Santos et al. 2015). This Atlantic Palaeolithic art, with great development in the Iberian Pen- insula, also begins to offer interesting data in England (Creswell Crag) and Brittany (Rocher de l'Impératrice) opening a new line of research, totally unknown until the last two decades(Bahn \& Pettitt 2009; Bueno Ramírez et al. 2016; Naudinot et al. 2017). 


\section{CONCLUSION}

The multiple approach adopted here allowed us to obtain a rigorous characterization of the studied collection. While the data managing tool allowed us to standardize and organize the information, the recording techniques and analytical characterization allowed us to collect more data. X-ray spectroscopy, coupled with scanning electron microscope and X-ray diffraction, were very important to determine raw material and possible surface treatments. SEM images were also extremely useful as a starting point to systematize the engraved lines.

Nevertheless, the obtained data is currently limited to a single sample and it will be necessary in the future to readjust the SPSS software questionnaire in order to obtain more, and more interesting results. Likewise, the investigations will have to include experimental references and be extended to more samples in order to complement and add data that will definitely enrich the discussion.

Taking into account the results, the multiple approach adopted can be applied to other collections, especially those in the northwest Iberia and Atlantic façade, in order to build a solid database that takes into consideration both arqueographic and archeometric data.

\section{Acknowledgements}

This study was supported by a Post-Doctoral grant (SFRH/ BPD/115051/2016) ascribed to the first author by FCT (Portuguese Foundation for Science and Technology). The project was done under the cooperation of Laboratório Hercules (Universidade de Évora, Portugal), Área de Prehistoria (Universidad de Alcalá, Spain) and Lab2PT (Universidade do Minho, Portugal). The authors thank an anonymous referee, who evaluted a previous version of the manuscript.

\section{REFERENCES}

Alcolea GonzÁlez J. J. \& Balbín Behrmann R. 2006. - Arte paleolítico al aire libre. El yacimiento rupestre de Siega Verde, Salamanca. Junta de Castilla y León, Arqueología en Castilla y León: 16. https://doi.org/10.14201/zephyrus2016771529

Aubry T. \& SAMPAIO J. D. 2012. - Novos dados para a abordagem técnica da arte rupestre e móvel do vale do Côa. Trabalhos de Arqueologia 54: 185-206. http://hdl.handle.net/10400.26/23382

BAHN P. G. 1997. — Journey Through the Ice Age, Weidenfeld \& Nicolson, London.

Bahn P. G. \& PetTitt P. (eds) 2009. - Britain's Oldest Art. The Ice Age art of Creswell Crags, English Heritage, London.

Bosinski G., D’ERrico F. \& SChILler P. 2001. — Die Gravierten Frauendarstellungen von Gönnersdorf. Franz Steiner Verlag, Gmbh Stutgart.

Botica N. 2017. - Contributo do Sistema de Informação 2ArchIS para o conhecimento das cidades Romanas de Braga e Lugo (Vol. 2). Servizo de Publicacións da Deputación de Lugo, Lugo.

Brady L. M., Hampson J. \& Domingo SANZ I. 2017. — Recording Rock Art: Strategies, Challenges, and Embracing the Digital Revolution, in DAvid B. \& MI J. (eds), The Oxford Handbook of the Archaeology and Anthropology of Rock Art: 1-28. https://doi. org/10.1093/oxfordhb/9780190607357.013.37
Bueno Ramirez P., Balbín Behrmann R. \& Alcolea González J. 2007. - Style V dans le bassin du Douro. Tradition et changement dans les graphies des chasseurs du Paléolithique supérieur européen». L'Anthropologie 111: 549-589. https:// doi.org/10.1016/j.anthro.2007.07.003

Bueno Ramirez P., Balbín Behrmann R. \& Alcolea González J. 2009. - Estilo V en el ámbito del Duero: Cazadores finiglaciares en Siega Verde (Salamanca), in Balbín Behrmann R. (ed.), Arte Prehistórico al aire libre en el Sur de Europa. Actas PAHIS, Junta de Castilla y León: 259-286.

Bueno Ramirez P., Balbín Behrmann R. \& Barroso Bermejo R. 2016. - Graphic Holocene expressions on the Atlantic Europe. Portugal, in SoAres J. (ed.), Social Complexity in a long term perspective (Vol. 16). Setúbal Arqueológica: 41-64.

D'ERrico F. 1992. - Technology, Motion, and the meaning of Epipaleolithic Art. Current Anthropologie 33 (1): 94-109. https:// doi.org/10.1086/204039

D’ERrico F. 1994. - L'art gravé azilien: De la technique à la signification, Éditions du CNRS, Paris (XXXIe Supplément à Gallia Préhistoire).

Fábregas Valcarce R., lombera Hermida A., Viñas Vallverdú R., Rodríguez-Álvarez X. \& Figueiredo S. S. 2015. Throwing light on the hidden corners. New data on Palaeolithic art from NW Iberia, in Bueno-Ramírez P. \& Bahn P. G. (eds), Prehistoric Art as Prehistoric Culture: Studies in Honour of Professor Rodrigo de Balbin-Behrmann. Archeopress Archaeology: 171-180.

FARBSTEIN R. 2011. - The significance of social gestures and technologies of embellishment in paleolithic portable art. Journal of Archaeological Method and Theory 18 (2): 125-146. https:// doi.org/10.1007/s10816-010-9085-9

Figueiredo S. S. 2017. - A arte esquemática do nordeste transmontano: contextos e linguagens, Associação dos Arqueólogos Portugueses (Monografias AAP,5), Lisboa. http://hdl.handle. net/1822/29085

Figueiredo S. S., Nobre L., Gaspar R., Carrondo J., Cristo Ropero A., Ferreira J., Silva M. J. \& Molina F. J. 2014. Foz do Medal Terrace - an open-air settlement with palaeolithic portable art. INORA: International Newsletter on Rock Art 68: $12-20$.

Figueiredo S. S., Xavier P. \& Nobre L. 2015a. - Placas móveis com grafismos rupestres paleolíticos do Terraço do Medal (Nordeste, Portugal): uma primeira análise a temas e estilos in Proceedings from the XIX International Rock Art Conference IFRAO [Arkeos 37]: 1573-1588. http://hdl.handle. net/10400.26/24954

Figueiredo S. S., Nobre L., Cristo Ropero A., Xavier P.,Gaspar R. \& CARRONDO J. 2015b. - Reassembly Methodology in Palaeolithic Engraved Plaques from Foz do Medal Terrace (Trásos-Montes, Portugal), in Medina-Alcaide, Ma Á., Romero Alonso A. J., Ruiz-Márquez R. Ma ${ }^{a}$. \& SAnchidrián Torti J. L. (eds), Sobre rocas y huesos:las sociedades prehistóricas y sus manifestaciones plásticas: 428-439.

Figueiredo S. S., Nobre L., Xavier P., Gaspar R. \& Carrondo J. 2016. - First approach to the chronological sequence of the engraved stone plaques of the Foz do Medal alluvial terrace in Trasos-Montes, Portugal. Arqueología y Prehistoria del Interior peninsular 04 Extra: 64-77. http://hdl.handle.net/10400.26/24953

FriTz C. 1999a. - La gravure dans l'art mobilier magdalénien, du geste à la représentation, Éditions de la Maison des Sciences de l'Homme, Paris (Documents d'Archéologie française 75).

FriTz C. 1999b. - Towards the reconstruction of Magdalenian artistic techniques: the contribution of microscopic analysis of mobiliary art. Cambridge Archaeological Journal 9 (2): 189-208. https://doi.org/10.1017/S0959774300015377

Fritz C. \& Tosello G. 2007. - The hidden meaning of forms: Methods of recording paleolithic parietal art. Journal of Archaeological Method and Theory 14: 48-80. https://doi:10.1007/ s10816-007-9027-3 
Gameiro, C., Aubry, T., Almeida, F., Dimuccio, L., Gabriel, S., Gaspar, R., Gomes, S., Fábregas Valcarce, R., Figueiredo, S. S., Manzano, C., Marreiros, J., Oliveira, C., Santos, A. T., Silva, M. J., Tereso, J. P. \& XaVier, P. 2020. — Archaeology of the Pleistocene-Holocene transition in Portugal: Synthesis and prospects. Quaternary International. https://doi.org/10.1016/j. quaint.2020.03.018

Gaspar R., Carrondo J., Nobre L., Rodrigues Z. \& Donoso G. 2014. - Espaço para a morte. O Terraço da Foz do Medal (vale do Sabor, nordeste de Portugal) durante a Idade do Bronze. Estudos do Quaternário10: 59-72.

Gaspar R., Ferreira J., Hernández F. M., García-Vadillo F., Rebelo P. \& Neto N. 2015a. - Away from the edges: A new Solutrean site in interior Iberia (Foz do Medal left bank, Sabor Valley, Northeast Portugal). Journal of Anthropological Research 71 (4): 545-564. https://doi:10.3998/jar.0521004.0071.405.

Gaspar R., Ferreira J., Carrondo J. \& Silva M. J. 2015b. - The use of quartz during the Upper Paleolithic and Early Mesolithic in Sabor valley (NW Iberia): The Foz do Medal case. Quaternary International 424: 98-112. https://doi:10.1016/j.quaint.2015.10.095.

Gaspar R., Ferreira J., Carrondo J., Silva M. J. \& García-VADILLO F. J. 2016. — Open-air Gravettian lithic assemblages from Northeast Portugal: The Foz do Medal site (Sabor valley). Quaternary International 406: 44-64. https://doi:10.1016/j. quaint.2015.12.054.

Giestal C. \& MARTINS M. 2000. - O projecto SIABRA: um sistema de informaçáo para a arqueologia urbana de Braga, in $3^{\circ}$ Congresso de Arqueologia Peninsular: 43-61.

GonZÁlez SAINZ C. 2010. — Unidad y Variedad de la Región Cantábrica y de sus Manifestaciones Artísticas Paleolíticas, in Las Cuevas con Arte Paleolitico en Cantábria, Asociación Cántabra para la Defensa del Patrimonio Subterráneo: 29-45.

LEROI-GOURHAN A. 1995 [1965]. - Préhistoire de l'art occidental. Nouvelle édition revue et augmentée, Citadelles \& Mazenod (L'Art et les Grands Civilisations, 1), Paris.

Lombera Hermida A. \& Fábregas Valcarce R. (eds) 2013. Cova Eirós. Primeras evidencias de arte rupestre Paleolitico en el Noroeste Peninsular, Andavira Editora SL, Santiago de Compostela.

LORBLANCHET M. 1989. - De l'art naturaliste des chasseurs des rennes à l'art géométrique du Mésolithique dans le Sud de la France. Almansor 7: 95-123.
MéLARD N. 2008. - Pierres Gravées de La Marche à Lussac-LesChâteaux (Vienne). Gallia Préhistoire (1) 50: 143-268.

Moro Abadía O. \& González Morales M. R. 2004. - 18641902: El reconocimiento del arte paleolítico. Zephyrus 57: 119-135.

Naudinot N., Bourdier C., Laforge M. Paris C., BellotGurlet L., Beyries S., Thery-Parisot I. \& Le Goffic M. 2017. - Divergence in the evolution of Paleolithic symbolic and technological systems: The shining bull and engraved tablets of Rocher de l'Impératrice. PLOS ONE 12 (3): e0173037. https:// doi:10.1371/journal.pone.0173037

PSP, 2009. - Plano de Salvaguarda do Património do Aproveitamento Hidroeléctrico do Baixo Sabor, EDP.

Rivero O. 2016. - Master and apprentice: Evidence for learning in palaeolithic portable art. Journal of Archaeological Science 75: 98-100. https://doi:10.1016/j.jas.2016.09.008.

Rivero O. \& Sauvet G. 2014. - Defining Magdalenian cultural groups in Franco-Cantabria by the formal analysis of portable artworks. Antiquity 88: 64-80. https://doi:10.1017/ S0003598X00050225.

Santos A. T. 2017. - A arte paleolítica ao ar livre da bacia do Douro à margem direita do Tejo: uma visão de conjunto, Faculdade de Letras da Universidade do Porto (Tese de Doutoramento), Porto. https://hdl.handle.net/10216/109327

Santos A. T., Sanches M. J. \& Teixeira J. C. 2015. - The Upper Palaeolithic rock art of Portugal in its Iberian context, in BUENO Ramírez P. \& Bahn P. G. (eds), Prehistoric Art as Prehistoric Culture. Studies in Honour of Professor Rodrigo de Balbin-Behrmann, Archaeopress Archeology: 123-133.

Santos A. T., Barbosa A. F., Aubry T., García Díez M. \& SAMPAiO J. D. 2018. - O final do ciclo gráfico paleolítico do Vale do Côa: a arte móvel do Fariseu (Muxagata, Vila Nova de Foz Côa). Portugalia 39: 3-92. http://hdl.handle. net/10451/36580

Tosselo G. 2003. - Pierres gravées du Périgord magdalénien: art, symbole, territoire, Centre National de la Recherche Scientifique, Paris.

Tosselo G. (2005). — Un contexto sociel para el arte mueble paleolítico en Francia?, in Arias Cabal P., OnTAÑón Peredo R. (eds), La materia del lenguaje prehistórico. El arte mueble paleolítico cantábrico en su contexto, Instituto Internacional de Investigaciones Prehistóricas de Cantabria, Santander: 53-65.

Submitted on 30 September 2019; accepted on 25 November 2019 published on 28 September 2020. 